\title{
Disability or Language Difference: How Do We Decide?
}

\author{
Douglas Carothers \\ Florida Gulf Coast University, USA \\ Christopher Parfitt \\ Florida Gulf Coast University, USA
}

\begin{abstract}
Increased globalization has resulted in increased attendance of language minority students in schools worldwide. These language differences confound efforts to identify students with disabilities. This case study provides a hypothetical example of interaction between language, social, and academic difficulties in determining existence of a disability and planning appropriate academic programming for a recently immigrated elementary school student named Filipe. Users of this case must analyze and synthesize cultural, behavioral, academic, and linguistic information as well as apply knowledge of legal requirements and best practices to determine an appropriate course of action for Felipe. This case study clarifies the need for additional research regarding how to distinguish between presence of a disability and normal challenges of adapting to a new language and culture in academic settings.
\end{abstract}

KEYWORDS: language minority, educational leadership, bi-lingual education, special education, English-language learner, principal responsibilities

\section{Introduction}

International migration has increased dramatically in the past thirty years, resulting in significant immigrant populations in G7 and other wealthy countries (Giovanni, Levchenko, \& Ortega, 2015). Because of this increased international immigration, the number of non-English speaking students attending English language schools has also increased (Faltis, 2014; Kim \& Helphinstine, 2017). Moreover, English language proficiency has been described as a challenge to academic achievement in countries around the world, including Australia (Watkins, Razee, \& Richters, 2012), Germany (Brandenburg et al., 2016), Canada (Roessingh \& Douglas, 2012), and Iran (Sadeghi, Kashanian, Maleki., \& Haghdoost, 2013). 
Regardless of where they are educated, the challenges imposed on second language (L2) students has also resulted in their disproportionate overrepresentation as having learning disabilities. This overrepresentation has been attributed to a variety of reasons including failure of achievement tests to use separate norms for language minority students (Aydin, Ozfidan, \& Carothers, 2017; Brandenburg et al., 2016), overreliance on teacher perceptions (Dever, Raines, Dowdy, \& Hostutler, 2016), and weakness in L2 students' listening and comprehension skills (Song, 2011), among other reasons. Recognition of the problem of disproportionate placement in special education programs first gained widespread recognition in the U.S. in the 1960s after publication of an article critical of placement rates for minority children in classes for intellectual disability (Dunn, 1968). This publication was quickly followed by litigation challenging the validity of assessing students in English to determine disability even though English was not their native language (Diana v. State Board of Education, 1970).

Today, nondiscriminatory evaluation of students for special education services is not only an integral role played by American schools, it is required by the Individuals with Disabilities Education Improvement Act (IDEA, 2004). The previously cited case of Diana v. State Board of Education (1970) laid the groundwork for non-discriminatory assessment of linguistically diverse students by requiring assessment in their primary language as well as English prior to making eligibility decisions. The concept of nondiscriminatory assessment was expanded in 1975 with the passage of the Education for All Handicapped Children Act. This law, most recently reauthorized in 2004 as the Individuals with Disabilities Education Improvement Act, additionally requires that tests be validated for the purpose for which they are being used, be administered by trained personnel, and be used to assess all areas of suspected disability. Further, the law clarified that no single procedure may be used to make eligibility decisions. Rather, IDEA (2004) requires that a variety of sources of information provide the basis for eligibility decisions and that eligibility be determined by a multidisciplinary team that includes, at a minimum, the following personnel:

- the parent

- a general education teacher,

- a special education teacher,

- a representative of the Local Education Agency (LEA) who is qualified to provide or supervise the provision of services to students with disabilities, is knowledgeable about the general education curriculum, and is knowledgeable about district resources,

- an evaluation specialist (who may also serve as another member of the team),

- others with special expertise, at the discretion of the parent or agency, and

- when appropriate, the child with a disability.

Culturally and linguistically diverse students are the fastest growing population in U.S. schools (Cushner, McClelland, \& Safford, 2012; Wilder, et al., 2017). Hence, despite longstanding attempts to distinguish between disability and cultural/linguistic diversity accurately, the number of minority students served in special education programs continues to grow (Damgaci \& Aydin, 2013 ; 2014). In fact, reducing the disproportionate placement of students from racial/ethnic 
Disability or Language Difference

minorities in special education programs is considered among the top three Congressional concerns related to enforcement of the IDEA (Albrecht, Skiba, Losen, Chung, \& Middelberg, 2012). Still, English-Language Learners (ELLs) remain more likely to be identified as having an intellectual or learning disability (Duran, 2008). In fact, the disproportionate representation of some groups in special education has been recognized as a significant problem for over 40 years (Dever, Raines, Dowdy, \& Hostutler, 2016).

Because of the alarming statistics regarding the overrepresentation of minority students in special education programs, teachers and educational leaders must ensure the use of nondiscriminatory assessment procedures when determining the educational needs of culturally/linguistically diverse students. Only this sort of careful approach will assure that all students have equitable opportunities to receive the services needed to achieve their full academic potential. This educational case study is presented as one means of sparking discussion and helping to prepare teachers and educational leaders to more accurately identify students with disabilities, students who are culturally/linguistically diverse but do not have disabilities, and students who are both culturally/linguistically diverse and who have disabilities.

\section{Objectives}

Given the following scenario and activities, pre-service and practicing teachers and educational leaders will:

1. Demonstrate an understanding of special education evaluation and placement procedures and the rights of children and families of children suspected of having a disability.

2. Practice skills in determining if a student is likely to meet eligibility criteria for special education services, services for English-Language Learners (ELLs), or both.

3. Demonstrate and describe the roles and responsibilities of multidisciplinary team members and of the parent/guardian of a student being considered for evaluation.

4. Describe procedures to ensure that communication between grade-levels is enhanced, allowing students to transition seamlessly while their needs are continuously met.

5. Identify procedures to ensure that all relevant stakeholders, including all appropriate family members, are involved in the making of critical educational decisions.

\section{Research Questions}

1. How well do preservice and practicing educators understand procedures for determination of eligibility for special education and related services and services for English Speakers of Other Languages (ESOL)?

2. What do preservice and practicing educators perceive as their greatest needs in learning to distinguish between those with disabilities and those learning to mediate a new language and/or culture?

3. What methods do preservice and practicing educators recommend to enhance communication regarding students experiencing academic and social/behavioral challenges, both among school personnel and between schools and families, including families from language and cultural minorities? 
Disability or Language Difference

\section{Case Narrative}

Felipe was born in Ciudad Juarez, Mexico and is the youngest of four children. Maria, his mother, reported that she did not smoke cigarettes or use intoxicating substances during her pregnancy, and that the pregnancy was normal and full-term. Felipe was born at home with the help of a midwife, a common practice in his culture. He was $50.8 \mathrm{~cm}$ (20 inches) long at birth and weighed $3.5 \mathrm{~kg}$ ( 7.7 pounds). Maria denied that Felipe had any traumatic injuries or accidents that could have affected his development during his preschool years, and he was reported to crawl, walk, and talk at the expected ages.

Until Felipe was four years old, his father Hector did whatever work he could find in Juarez including agricultural work and helping friends with maintenance and construction tasks around their homes. Because he did not have a high school diploma or speak fluent English, Hector was not able to find a steady job in the maquiladora (manufacturing center) despite the explosive growth of factories in Juarez. As such, he often took short-term jobs that required long hours of work for relatively little pay, but he vowed that his children would have a brighter future. Maria alternated her time between staying at home with the children, performing odd jobs around the town, and doing agricultural work. Even though both of his parents worked hard, Felipe's family struggled financially, and his parents often talked about how getting a better education could improve life for their children.

The family had many discussions regarding the pros and cons of moving to the United States while Felipe was still young. "Opportunities are too limited here, and my sister says we can move in with them," Maria told Hector. "You'll have better opportunities for work in Texas. Also, it will be better for the children, and Felipe will be able to start school in America and learn to speak English like everyone else there. Before long we will have a house for ourselves, and our whole lives will be better. I'll bet that within a year or two, the kids will be just like kids born in America." The children sounded excited about the possibilities during these conversations, but Hector usually sat silently and listened. Based on his experiences, life was rarely as easy as Maria was saying it would be in the United States. Still, he also knew how difficult life was in Juarez.

Hector finally relented, and the family packed its belongs and moved to El Paso, Texas shortly before Felipe turned five years old. Once there they began sharing a house with Maria's sister, who also lived with her husband and their two children. Still, it was hard for Hector to find work, especially without a green card, so he began performing migrant labor across the Southwestern United States and was frequently away from home. Maria had less difficulty finding work, but it consisted mainly of housekeeping in the middle-class neighborhoods of El Paso during the day while her sister watched the children. Then Maria watched the children in the evenings while her sister and two other women operated a taco truck. The children were a happy group of six and frequently played outside. Though there were the occasional spats one would expect between siblings or close relatives, the children got along well with one another.

Shortly after moving to El Paso, Hector and Maria enrolled Felipe in Jim Bowie Elementary School (JBES), a school that housed about 550 students. Because they were living with Maria's sister in a house with more than one family, no proof of residency was required, and when asked for her identification Maria did not understand the question and smiled blankly. The worker on duty, overwhelmed due to the absence of a colleague, simply generated automated 
Disability or Language Difference

identification numbers for Felipe and his siblings and the students were enrolled. There was happy chatter around the dinner table that evening as Hector and Maria looked at their children, confident that they had taken actions to make the future brighter for each of them.

Felipe noticed on his first day at school that about $80 \%$ of his classmates were also of Hispanic descent. The administrators determined that Felipe and his siblings qualified for the freelunch program, but nobody was embarrassed because it seemed that nearly all the students qualified for this benefit. Because many of the students were of the same heritage and had similar home situations, Felipe seemed comfortable at his new school. He went through the normal vision and hearing screenings and passed them with flying colors. He was placed in a kindergarten classroom with 19 other students and a teacher who taught in both Spanish and English. This was Felipe's first exposure to the English language and it was not uncommon for students at JBES to attend classes that taught the students bilingually.

Around the house, Felipe had regular chores that he performed, including taking out the trash, making his bed, and cleaning the room he shared with a brother and a cousin. He looked forward to when his father was home, and enjoyed watching him tinker with mechanical tasks such as odd repairs around the house and working on the car. Felipe was quick to learn the Spanish names of the automotive tools that he was asked to pass to his father and enjoyed working on hands-on tasks. Because Hector spoke limited English, however, Felipe did not learn the English names of the tools they used.

Felipe also seemed to fit in well with the other children in first grade. He continued to attend class with a bilingual teacher. Felipe's teacher, Mrs. Rodriguez, was in her early 30s and was in her $10^{\text {th }}$ year of teaching. To Mrs. Rodriguez, Felipe appeared to be a cheerful and compliant boy. However, on two separate occasions he got into loud arguments with one of the Anglo boys in the class. Though Felipe said it was because the other boy had started the argument by calling him names during English language arts instruction, he was sent to the office on both occasions. On the second incident, Felipe was told that if it happened again he would be suspended. Felipe did not argue with his teacher or the administrator when he went to the office. Relatively soon after these arguments occurred, Felipe's teacher noted that he seemed to be having difficulty in keeping up with his classmates academically, though he did very well in Math-related subjects. The other students were progressing on grade level with all subjects, yet Felipe did not seem to respond to the same strategies as his classmates. Reading, Science, and Social Studies were relative areas of concern for Felipe, although he seemed to perform relatively well on his Math assessments. Mrs. Rodriguez wondered whether she should call Hector and Maria for a conference, but finally decided not to worry them. Instead, she contacted Felipe's kindergarten teacher to see if she had noticed any academic or social difficulties (Ersoy, 2015; Deniz \& Ersoy, 2016) or had found any teaching strategies that proved especially effective for Felipe. Mrs. Rodriguez also asked her colleague whether it seemed an appropriate to call Mrs. Mingel, the school psychologist, but was told that because the psychologist served three elementary schools, it was more appropriate to try in-class interventions first. When the kindergarten teacher responded that Felipe had seemed perfectly typical, Mrs. Rodrigues reflected. She had seen many students who initially struggled more than Felipe but had ultimately been successful, Because of this, Mrs. Rodriguez decided to keep her concerns to herself while continuing to monitor Felipe's performance closely. 
Disability or Language Difference

Additionally, Mrs. Rodriguez began to carve out 15 minutes near the end of each day to help Felipe and two other children improve their reading skills. During this time, she focused instruction on the teaching of sight words by using flash cards. She emphasized those that followed a "vowelconsonant" pattern (e.g., it, at, and an), and the longer words that could be made by using them as roots (e.g., sit, sat, fan, etc.). As it turned out, her decision not to report Felipe's problems was validated. Although he finished the year near the bottom of his class in several subjects, Felipe did well enough to advance to second grade.

In the second grade, Felipe was placed in a class in which the only language used for instruction was English. His progress in language arts and content classes continued to slow, and even his Math work began to suffer. Felipe's new teacher, Miss Black, was in her fifth year of teaching and in her first year at JBES. Felipe liked his new teacher because she seemed to care about his well-being and grades. Still, Felipe continued to fall behind his classmates in academic assessments, especially in Reading. Miss Black noticed that in group-work situations Felipe remained quiet while his group mates worked. He never asked questions, yet he did not seem frustrated either. Miss Black was careful to place Felipe with students he appeared to like, as she did not want to discourage him from progressing academically. Also, though she did not provide Felipe with the small group instruction in reading that he had received in first grade, she did allow him and his friends to gather and read materials of their choosing when there was available time in class.

During recess, and other opportunities for social interaction, Felipe began to associate mainly with the other Hispanic students in the class. His arguments with the Anglo student continued, and he began to get into arguments with other Anglo students. Miss Black was concerned with Felipe's recent behaviors and academic struggles, so she tried twice to plan for parental meetings, but Felipe's father Hector was out of town both times. Maria came to the school to meet with Mrs. Black without Hector, and because Maria spoke little English, she brought her sister with her to translate. Unfortunately, the translations were inaccurate because Maria's sister was also unable to understand much of Miss Black's specialized terminology. At the end of the year Miss Black decided to pass Felipe even though his academic performance was marginal and he could have easily been retained.

At home, Felipe continued to interact with a wide circle of neighborhood friends and was diligent about performing his chores. Felipe got along well with these friends and they played together often. Additionally, Felipe was beginning to show a definite aptitude for making minor mechanical repairs, including changing flat tires and performing other repairs on his and his friends' bicycles. When his father was at home, Felipe spent much time working with him and learning automobile and home maintenance skills. As a result, his friends often came to him for help with mechanical tasks or with problems that needed tedious repairs. Hector was proud that Felipe could concentrate on a task for hours until he fixed the problem, and because Felipe experienced so few problems at home, his father assumed he also did well in school. Further, because she did not want to concern Hector, Felipe's mother did not mention her visits to the school. She now trusted Felipe to run errands to the bodega on the corner and to return with the correct change. Felipe was responsible with his mother's money and with his friend's belongings. Despite his struggles in school, he knew how to be honest and work hard. 
In August of 2013, Felipe started third grade with Mrs. Gonzales. She was a veteran teacher at JBES, and because she was respected for her teaching, she was also a grade level team leader. Mrs. Gonzales quickly noticed that Felipe continued to fall further behind the other students in academic subjects and that he seemed to be limiting his social interactions to only Hispanic friends. He especially struggled with Reading and Social Studies, and though his most successful academic area was Math, he was no longer near the top of the class in Math performance. Felipe still did well in special classes such as Art and Physical Education.

After observing Felipe struggle with academics and social interactions, Mrs. Gonzales suggested to the Principal, Mr. Hernandez, and the school's Exceptional Student Education (ESE) contact, Mrs. Suarez, that Felipe be assessed for eligibility for special education services. The three discussed the upcoming State of Texas Assessments of Academic Readiness (STAAR) testing in which Felipe would be required to participate when he entered fourth grade, and wondered about the implications of Felipe being identified as an English Language Learner or as a student with a disability. Following their discussion, Mrs. Gonzales called Maria. Though Hector was out of town and she wished she could have discussed it with him, she remembered their previous conversations about the importance of education and agreed that she wanted to do whatever was necessary to help Felipe succeed in school. She was also aware that Felipe would not react well if he was retained in grade. She explained the family history to Mrs. Gonzales, and even told her that the children's education was a large part of the reason that the family had decided to move to El Paso. When Mrs. Gonzales heard this, she asked Maria to sign papers indicating that she was giving informed consent for an evaluation. Maria signed the papers but did not talk to Felipe or Hector about her conversations with the school.

Felipe became angry and sullen when he found out that his mother had requested that he be evaluated for eligibility for special education services. He screamed at her, "Now you think I'm stupid too, just because I don't speak good English. I wish we stayed in Mexico and never moved here. School was fun there." Two days later, he refused to follow Mrs. Gonzales' instructions in class, swore at her, and threw a book across the room. In response, Mrs. Gonzales sent Felipe to the office to meet with Mr. Hernandez, who in turn called Felipe's home. This time however, Hector answered the phone. When told about Felipe's behavior and what was going on at the school, Hector asked Mr. Hernandez if he could come immediately to the school for a meeting. Mr. Hernandez said yes, and a meeting was held between Mr. Hernandez and Felipe's father while Felipe remained in the room with the two adults. Though he was not angry, Hector stated that he was completely unaware of his wife's actions and asked Mr. Hernandez for an explanation of both the school's actions and his rights as a parent. He also asked about available resources that would enable him to assist Felipe at home and assured Mr. Hernandez that despite his frequent travels, he wanted to play a primary role in his children's lives.

\section{Teaching Notes}

School leaders must strike a careful balance between preserving the right of each student suspected of having a disability to receive a free appropriate public education while also being mindful of the overrepresentation of minority students in special education. To prepare the class to fully address the legal issues present in this case, it is recommended that students first read the Notice of Procedural Safeguards (Texas Education Agency, 2017), a statement of federal 
Disability or Language Difference

requirements and parents' rights that must be given to parents before initiating processes to determine eligibility for special education services. Likewise, though this case could have occurred anywhere, this story is set in Texas so it is recommended that students also read The Parents' Guide to the Admission, Review, and Dismissal Process (Texas Education Agency, 2016).

\section{In-class activity: Application of a multi-disciplinary team approach}

The instructor should place students in groups of six, and allow students $15-20$ minutes to read the case, if they have not done so already. Then, each student should self-select or be assigned to one of the following roles so that each role is filled: Mrs. Gonzales (third-grade general education teacher), Mrs. Suarez (JBES' Exceptional Student Education Coordinator), Mr. Hernandez (Principal of JBES), Maria (Felipe's mother), Mrs. Mingel (a school psychologist whose time is divided between three schools, but who can provide general information regarding types of needed assessment and her availability to provide them), and Mr. Edwards (the school's ESOL Coordinator, who may be able to recommend other interventions that have not yet been tried). Based upon the above narrative, students should simulate a multi-disciplinary meeting to consider the following issues:

- What additional existing information should be provided to assist in determining if Felipe is eligible for special education and related services? Are there additional interventions that could be attempted to reduce the need for Felipe to receive a special education label?

- What additional information should be collected to determine if Felipe's problems are due to a language difference?

- What other types of data should be collected to determine the sources of Felipe's academic and social problems in school? Who should be responsible for collecting these data? If you were the school ESE contact, what steps would you take before testing Felipe? What steps would you take to start the testing process?

If the school district's special education staff decides that they do not want to evaluate Felipe, what are they legally required to do? What recourse is available to Hector and Maria if they want to have Felipe evaluated but the school district refuses? What recourse is available to Hector and Maria if the district evaluates Felipe but they disagree with the results of the evaluation? How the principal approach the situation to ensure Felipe should receive appropriate educational services?

If the school district determines that Felipe is eligible for services but Maria and Hector refuse to provide consent for the initiation of services, what are the implications? What steps can the district take to ensure that Felipe receives the services for which he is qualified? How should the principal address all the stakeholders to build consensus on services for Felipe?

\section{Discussion Questions}

1. If you were a school principal responsible for the education of many students, at what point would you like teachers to inform you about situations of concern with individual students? What procedures could you put in place that would both guarantee the professional autonomy of teachers and create a conduit for free communication? How would you facilitate communication between teachers of struggling students as children progress through the grades? 
Disability or Language Difference

2. In addition to the probable use of response to intervention, how would you realign the use of existing school resources to ensure that all students experiencing difficulties, regardless of whether they are suspected of having a disability, are provided with prompt opportunities for academic or behavioral remediation?

3. What methods can school principals employ to ensure that communications with the home are presented to all decision-makers in the family? Is the use of special approaches necessary when the parents do not live together or when one parent is frequently out of town or otherwise unavailable?

4. Is it a principal's right or responsibility to encourage English literacy among family members of his/her students? If so, what steps can principals take to ensure that all family members are aware of community resources that will facilitate their increased ability to speak, read, and write English?

\section{Conclusion}

This educational case study discussed increased global migration that is resulting in more L2 students attending English-speaking schools around the world (Kim \& Helphinstine, 2017) . Evidence shows that L2 students attending English language schools are identified as having learning disabilities at higher rates than are native English-speaking students regardless of the country in which they are being educated, and a variety of explanations were posited for why this is happening (Brandenburg et al., 2016; Citamak \& Yigit, 2012; Corona et al., 2017; Dever et al., 2016; Faltis, 2014; Inceli, 2015; Kaya, 2015; Song, 2011). Disproportionately high rates of special education placement for minority students has been recognized as a problem in the U.S. for decades (Zhang, Katsiyannis, Ju, \& Roberts, 2014) and legal remedies to the overrepresentation of L2 students in the US began in 1970 (Diana v. State Board of Education, 1970). Despite decreases in U.S. special education placements for some minority groups in certain disability categories, however, ELLs are increasingly being identified as having LD, especially in certain U.S. states (Sullivan, 2011).

The failure of legislation to reduce overrepresentation of ELLs as having LD points to the need for other solutions to this global problem. Increased reliance on culturally and linguistically sensitive early intervention offers hope, as does increased use of non-verbal assessment instruments. Recent calls for the school psychology practices to be better aligned with ecological systems theory (EST) is also encouraging (Burns, 2013). This approach requires assessors to examine a student's entire environment, including home, school, and community, and if successful in reducing the misidentification of L2 students as LD, it can be useful despite the school's geographic location. Regardless of which approach or combination of approaches is ultimately selected, however, more research is clearly needed to discover accurate ways of distinguishing between disability and language differences as our planet becomes increasingly interconnected and its inhabitants increasing intermingle. 


\section{References}

Albrecht, S. F., Skiba, R. J., Losen, D. J., Chung, C., \& Middelberg, L. (2012). Federal policy on disproportionality in special education: Is it moving us forward? Journal of Disability Policy Studies, 23(1), 14-25. http://dx.doi.org/10.1177/1044207311407917

Aydin, H., Ozfidan, B., Carother, D. (2017). Meeting the Challenges of Curriculum and Instruction in School Settings in the United States. Journal of Social Studies Education Research, 8(3), 76-92.

Brandenburg, J., Fischbach, A., Labuhn, A. S., Rietz, C. S., Schmid, J., \& Hasselhorn, M. (2016). Over identification of learning disorders among language-minority students: Implications for the standardization of school achievement tests. Journal for Educational Research Online, 8 (1), 42-65.

Burns, M. K. (2013). Contextualizing school psychology practice: Introducing featured research commentaries. School Psychology Review, 42(3), 334-342.

Corona, R., Velazquez, E., McDonald, S., Avila, M., Neff, M., Iglesias, A., \& Halfond, R. (2017). Ethnic labels, pride, and challenges: A qualitative study of Latinx youth living in a new Latinx destination community. Journal of Ethnic and Cultural Studies, 4(1), 113.

Citamak, Y. \& Yigit, I. (2012). From Student's Table to Teacher's Desk. International Journal of New Trends in Arts, Sports \& Science Education 1(2), 1-7.

Cushner, K., McClelland, A., \& Safford, P. (2012). Human diversity in education: An intercultural approach (7th ed.). New York, NY: McGraw-Hill.

Damgaci, F. \& Aydin, H. (2013). Faculty Members' Perception on Multicultural Education. Electronic Journal of Social Sciences, 12(45), 325-341.

Damgaci, F. \& Aydin, H. (2014). An Analysis of Academicians' Perceptions of Multicultural Education: A Turkish Experience. The Anthropologist, 18(3), 817- 833.

Deniz, M., \& Ersoy, E. (2016). Examining the Relationship of Social Skills, Problem Solving and Bullying in Adolescents. International Online Journal of Educational Sciences, 8(1), 1 -7.

Dever, B. V., Raines, T. C., Dowdy, E., \& Hostutler, C. (2016). Addressing disproportionality in special education using a universal screening approach. The Journal of Negro Education, 85(1), 59-71.

Diana v. California Board of Education, No. C-70-37. (1970). Diana v. California Board of Education, Complaint for Injunction and Declaratory Relief (Civil Rights), 1973. Retrieved from https://law.justia.com/cases/federal/district-courts/FSupp/359/1053/1471315/

di Giovanni, J, Levchenko, A. A., \& Ortega, F. (2015). A global view of cross-border migration. Journal of the European Economic Association, 13, 168-202. https://doi.org/10.1111/jeea.12110

Dunn, L. (1968). Special education for the mildly retarded: Is much of it justifiable? Exceptional Children, 35, 5-22.

Duran, R. P. (2008). Assessing English-language learners' achievement. Review of Research in Education, 32, 292-327.

Ersoy, E. (2015). Assessment of Adolescent Perceptions on Parental Attitudes on Different Variables. Journal of Education and Training Studies, 3(5), 165-176.

Faltis, C. (2014). Toward a Race Radical Vision of Bilingual Education for Kurdish Users in Turkey: A Commentary. Journal of Ethnic and Cultural Studies, 1(1), 1-5. 
Disability or Language Difference

Inceli, O. (2015). The Perceptions of English Teachers to the SIOP® Model and Its Impact on Limited English Proficiency. Journal of Ethnic and Cultural Studies, 2(1), 15-28.

Individuals with Disabilities Education Improvement Act of 2004. (2004). The Individuals with Disabilities Education Act (IDEA) Annual School District Determinations (2004). Retrieved from http://www.p12.nysed.gov/specialed/idea/

Kaya, Y. (2015). The Opinions of Primary School, Turkish Language and Social Science Teachers regarding Education in the Mother Tongue (Kurdish). Journal of Ethnic and Cultural Studies, 2(2), 33-46

Kim, K. \& Helphenstine, D. T. (2017). The perils of multi-lingual students: “I'm not LD, I'm L2 or L3." Journal of International Students, 7(2), 421-428.

Roessingh, H., \& Douglas, S. R. (2012). Educational outcomes of English language learners at university. The Canadian Journal of Higher Education, 42(1), 80-97.

Sadeghi, B., Kashanian, N. M., Maleki, A., \& Haghdoost, A. (2013). English language proficiency as a predictor of academic achievement among medical students in Iran. Theory and Practice in Language Studies, 3(12), 2315-2321.

Sullivan, A. L. (2011). Disproportionality in special education identification and placement of English language learners. Exceptional Children, 77(3), 317-334.

Song, M. Y. (2011). Note-taking quality and performance on an L2 academic listening test. Language Testing, 2 (1), 67-89. DOI: 10.1177/0265532211415379

Texas Education Agency. (2016). The parents' guide to the admission, review, and dismissal process. Retrieved from file:///E:/2017\%202018/Scholarship/Manuscripts/Revised\%20materials\%20Case\%20stud y/ARD_Guide_ENG.pdf

Texas Education Agency. (2017). Notice of procedural safeguards. Retrieved from http://framework.esc18.net/Documents/Pro_Safeguards_ENG.pdf

Watkins, P. G., Razee, H., \& Richters, J. (2012). I'm telling you ... the language barrier is the most, the biggest challenge: Barriers to education among Karen refugee women in Australia. Australian Journal of Education, 56(2), 126-141. http://dx.doi.org/10.1177/000494411205600203

Wilder, L., Sanon, D., Carter, C., \& Lancellot, M. (2017). Narrative Ethnographies of Diverse Faculty in Higher Education:"Moral" Multiculturalism among Competing Worldviews. Journal of Ethnic and Cultural Studies, 4(2), 1-12.

Zhang, D., Katsiyannis, A., Ju, S., \& Roberts, E. (2014). Minority representation in special education: 5-year trends. Journal of Child and Family Studies, 23(1), 118-127. doi:http://dx.doi.org.ezproxy.fgcu.edu/10.1007/s10826-012-9698-6

Manuscript received December 03, 2017 Final revision received December 19, 2017 Accepted December 28, 2017

Dr. Doug Carothers is an Associate Professor of Special Education at Florida Gulf Coast University, 10501 FGCU Blvd. South, Fort Myers, FL 33965; E-mail: dcarothe@fgcu.edu His major responsibility is providing initial and enhanced preparation for those serving students with disabilities in public school settings. He does this by teaching both undergraduate and graduate courses on special education history and law, characteristics and assessment of disabilities, transition education, and instructional methods for students with support needs that range from intermittent to pervasive. 
Dr. Christopher M. Parfitt is the coordinator for program assessment for the College of Education at Florida Gulf Coast University. 10501 FGCU Blvd. South, Fort Myers, FL 33965; E-mail: CParfitt@fgcu.edu

He is responsible for accreditation, continuous-improvement initiatives, and compliance aspects for the college. In addition to administrative responsibilities, Dr. Parfitt serves as an adjunct professor for educational leadership courses. Dr. Parfitt served as school administrator, worked in school district human resources, and was a teacher for several years. He has authored or coauthored multiple scholarly conference presentations and peer-reviewed article. 